\title{
The environmental aspect of the Eurasian integration of trans- border regions of Siberia and the Far East
}

\author{
$T A$ Selishcheva $^{1, *}, V M$ Nuyanzin $^{1}, O P$ Iljina $^{2}, E S$ Gavrilyuk $^{3}$, and $S A$ Gorodkova $^{4}$ \\ ${ }^{1}$ Saint-Petersburg State University of Economics, Department of General Economic Theory and History of Economic Thoughts, Saint \\ Petersburg, Russia \\ ${ }^{2}$ Saint-Petersburg State University of Economics, Department of computer science, Saint Petersburg, Russia \\ ${ }^{3}$ Saint Petersburg National Research University of Information Technologies, Mechanics and Optics, Department of Production \\ Management and Technology Transfer, Saint-Petersburg, Russia \\ ${ }^{4}$ Siberian University of Consumer Cooperatives, Branch of the Transbaikal Institute of Entrepreneurship, \\ Chita, Russia
}

\begin{abstract}
The article considers the environmental problems of the trans-border regions of Siberia and the Far East in the conditions of the Eurasian integration. The environmental consequences of functioning of the economies of the near-border East Asian countries for the Russian trans-border regions are shown. Russian trans-border Siberian and Far Eastern regions perform economic cooperation with the countries of the AsiaPacific region in various sectors of the economy: mining and manufacturing, agriculture and forestry, nuclear energy, transport and other industries. At the same time, the environmental risks of such cooperation are not always evaluated. This is evidenced by the deteriorating environmental situation in the regions under consideration. The article proposes measures to improve the state environmental regulation of the Eurasian integration process: the development of low-carbon energy and energy-efficient technologies, the use of modern agricultural technologies, focus on the formation of a green economy, coordination of environmental legislation of the cooperating Eurasian states.
\end{abstract}

\section{Introduction. Formulation of the problem}

Sustainable development assumes a harmonious combination of economic, environmental and social aspects [1]. Trans-border regions of Siberia and the Far East are actively involved in economic integration with East Asian countries. The serious environmental problems of the trans-border Russian regions restrain their progress towards sustainable development. Nature management is global irregardless what is happening in a particular region, therefore the environmental problems [2] can be solved only by joint efforts of the countries participating in the Eurasian integration. The problem of the environmental consequences of the economic cooperation of the Russian trans-border regions with the border East Asian countries is not sufficiently studied and is of interest.

\section{Research issues}

We pose the following issues in our research:

1. To explore the environmental consequences of economic cooperation between trans-border Siberian and Far Eastern regions with East Asian countries in a sectoral perspective.
2. To analyze the environmental problems arising during cooperation between the Russian trans-border regions with the PRC and Mongolia.

3. To conduct a comparative analysis of the environmental ratings of Russian trans-border regions with average statistical indicators for Russia and to propose measures of state regulation to improve the environmental situation.

\subsection{The aim of the study}

The aim of the study is to identify the environmental problems of the Russian trans-border regions of Siberia and the Far East in Eurasian integration and propose measures to address them.

\subsection{Research methods}

We used the following research methods:

1. To achieve the goal of the study, the evolutionary and systemic approach are used, which focuses on the analysis of environmental changes in the Russian transborder regions, which are considered as a system that is constantly changed in the conditions of the Eurasian integration.

2. The method of comparative analysis of statistical data, which consists in comparison of individual

\footnotetext{
* Corresponding author: selishcheva@ $@$ list.ru
} 
Table 1. Indicators of the environmental impact of individual regions of Siberia and the Far East per capita [9].

\begin{tabular}{|c|c|c|c|}
\hline Region/country & $\begin{array}{c}\text { Emissions of pollutants } \\
\text { from stationary sources, } \\
\mathbf{k g} / \mathbf{p e r s o n}\end{array}$ & $\begin{array}{c}\text { Discharges of polluted } \\
\text { water, } \mathbf{3} \text { /person }\end{array}$ & $\begin{array}{c}\text { Generation of production } \\
\text { and consumption waste, } \\
\text { t/person }\end{array}$ \\
\hline Amur Oblast & 155 & 95 & 4 \\
\hline Jewish Autonomous Oblast & 142 & 82 & 109 \\
\hline Zabaykalsky Krai & 117 & 32 & 43 \\
\hline Irkutsk Oblast & 284 & 223 & 21 \\
\hline Primorsky Krai & 93 & 147 & 61 \\
\hline Republic of Buryatia & 117 & 33 & 64 \\
\hline Khabarovsk Krai & 85 & 133 & $\mathbf{3 6}$ \\
\hline Russian Federation & $\mathbf{1 2 8}$ & $\mathbf{1 0 6}$ & \\
\hline
\end{tabular}

environmental indicators in order to detect their similarities and differences, revealed existing environmental problems in trans-border regions.

3. The use of formal logic techniques made it possible to identify the consequences and causes of a difficult ecological situation in the regions under study as a result of economic integration with East Asian countries.

\section{The results of the study}

Currently, the development of the regions of Siberia and the Far East is the national priority of the economic policy of the Russian government. The economic cooperation of the trans-border regions of Siberia and the Far East with the East Asian countries bordering them is expanding in the mining and manufacturing industries, agriculture and forestry, nuclear energy, transport and other industries. At the same time, the environmental risks of such cooperation are not always evaluated.

This economic cooperation is most active with China. In 2015, an agreement was signed on the conjunction of the Eurasian Economic Union and the Chinese initiative "The Silk Road Economic Belt" (SREB), where a large role is assigned to the Russian trans-border regions. However, this pairing of two projects is ambiguously evaluated by some Russian scientists [3]. The territories of priority development are located along the SREB. Only for 2016-2017 80\% of investments from the countries of the Asia-Pacific region fall upon the PRC. 28 projects are being implemented in the Far Eastern region, with the participation of Chinese capital, in which about 4 billion dollars of Chinese investments have been invested [4].

As a result of the rapid economic growth of China, there is a constant deterioration of the environment, an increase in wastewater discharges, emissions of pollutants into the atmosphere and an increase in industrial waste [5]. Sometimes Chinese entrepreneurs, under the guise of investment from China, are transferring outdated and environmentally dirty production to the Russian border regions. In China itself, there is a focus on developing low-carbon energy and energy-efficient technologies, a policy has been taken to preserve its own natural resources and the environment, and a policy has been taken towards a green economy [6].
In 2010-2018 the trans-border regions of Siberia and the Far East saw the increased emissions of pollutants, industrial wastes, discharge of polluting waters due to the increase in the scale of mining operations, including those supplied to China [7], [8]. The indicators of environmental impact per capita in most Russian Siberian and Far Eastern regions of trans-border interaction with China and other East Asian countries exceed the average for Russia (see Table 1).

The increase in emissions is explained by the fact that solid fuel is used for the production of electric and thermal energy in most regions of the Far East (with the exception of the Amur Oblast), the Republic of Buryatia and the Zabaykalsky Krai. Ecology is also worsened by the extraction of fuel and energy minerals in the considered regions. Cement production in the Jewish Autonomous Oblast and aluminum production in the Irkutsk Oblast pollute the atmosphere. Enterprises of the military-industrial complex and enterprises producing vehicles located in the Khabarovsk Krai and Zabaykalsky Krai make a great contribution to the creation of the gross regional product. Increasing production at these enterprises potentially makes it possible to reduce harmful emissions.

Since 2007, in Russia, the "Environmental Rating of the Subjects of the Russian Federation" is calculated once a quarter, which takes into account such indicators as: air, water, discharges, emissions, government responsibility, activity of public organizations and other criteria. In this case, 4 indices are calculated: environmental, industrial-ecological, socio-ecological, and a complex index. Table 2 shows the dynamics of trans-border Russian regions in the environmental rankings for 2010, 2015 and 2018. 
Table 2. Ranking positions of trans-border regions in the environmental rating of the subjects of the Russian Federation in 2010-2018 [10], [11], [12].

\begin{tabular}{|c|c|c|c|c|}
\hline \multirow[t]{2}{*}{ Region } & \multicolumn{3}{|c|}{$\begin{array}{l}\text { Ranking position in the } \\
\text { environmental rating }\end{array}$} & \multirow{2}{*}{$\begin{array}{c}\text { The rating } \\
\text { dynamics } \\
(2018- \\
2010)\end{array}$} \\
\hline & 2010 & 2015 & 2018 & \\
\hline $\begin{array}{c}\text { Primorsky } \\
\text { Krai }\end{array}$ & 25 & 53 & 61 & -36 \\
\hline $\begin{array}{c}\text { Khabarovsk } \\
\text { Krai }\end{array}$ & 39 & 46 & 63 & -24 \\
\hline Amur Oblast & 41 & 67 & 68 & -27 \\
\hline $\begin{array}{c}\text { Zabaykalsky } \\
\text { Krai }\end{array}$ & 79 & 66 & 75 & +4 \\
\hline $\begin{array}{c}\text { Jewish } \\
\text { Autonomous } \\
\text { Oblast } \\
\end{array}$ & 23 & 80 & 76 & -53 \\
\hline $\begin{array}{c}\text { Republic of } \\
\text { Buryatia }\end{array}$ & 8 & 35 & 80 & -78 \\
\hline Irkutsk Oblast & 44 & 48 & 82 & -38 \\
\hline
\end{tabular}

As it can be seen from table 2, in 2018 all the regions under consideration had poor ranking in the environmental rating: from the 61st place (Primorsky Krai) to the 82nd place (Irkutsk Oblast). All regions (with the exception of the Zabaykalsky Krai) had a negative rating dynamics, but the Zabaykalsky Krai has a rather low 75th rating position. The Republic of Buryatia is experiencing the strongest drop of the rating position (from the 8th place in 2010 to the 80th in 2018).

The main areas of regional cooperation between the People's Republic of China and the Russian Federation in the Far East and Siberia have become the extractive industries, agriculture and forestry.

Entrepreneurs from China are actively investing in the creation of agricultural production in the territories of the border Siberian and Far Eastern Russian regions. There are more than 150 Heilongjiang agricultural enterprises operating in Russia, which account for $82 \%$ of agricultural land leased by Chinese entrepreneurs (500 thousand hectares) and which are located mainly in the Far East [13]. Chinese entrepreneurs in the Jewish Autonomous Region control up to $80 \%$ of agricultural land, and soybeans are grown on $85 \%$ of them. It makes the land barren after 10-15 years of cultivation of this crop [14]. Chinese manufacturers do not always adhere to Russian agrotechnical norms, which can lead to depletion of land.

In 2015, the Russian "Far East Development Fund" and the Chinese "Managing Company of the AsiaPacific Food Fund of China" signed an agreement on the creation of a "Russian-Chinese agribusiness development fund in the Far East" with an initial capital of 13 billion rubles. The Agreement provides mechanisms to prevent negative consequences in the field of international cooperation between the two countries in the field of agriculture. At the same time, only Russian companies can receive the Far Eastern lands for farming, and the use of modern agricultural technologies that ensure the careful exploitation of agricultural lands is imperative. $80 \%$ of workers should be Russians and foreign workers should account not more than $20 \%$. Agricultural projects are financed in proportion: $90 \%$ are contributed by the Chinese party and $10 \%$ by the Russian party [15].

Cooperation in agriculture between the PRC and the Russian Federation is also carried out in the form of creating economic parks. For example, the "Heilongjiang Provincial Modern Agriculture Park in Primorsky Krai" was created. On the basis of this park, large livestock breeding complexes for raising cattle and pigs are functioning. In 2015, this park was included in the scope of the Silk Road Economic Belt project. The Ministry of Eastern Development is actively developing cooperation in the field of agriculture with Japan and South Korea. It is planned to create a "Russian-Korean Agro-Industrial Investment Fund", the purpose of which is to invest in agricultural projects in the Far East.

Serious environmental problems have arisen in the logging industry in the Far East, where $25 \%$ of the timber reserves of the Russian Federation are concentrated. This industry is very much focused on the Chinese market, where about $95 \%$ of the total volume of unprocessed wood exported from the Far East is exported (for comparison: $2.5 \%$ is exported to the Republic of Korea, $2.1 \%$ is exported to Japan). In addition, $85 \%$ of the processed timber is exported to China from the Far East (for comparison: $9.5 \%$ to the Republic of Korea, 2.6\% to Japan, total export) [16].

In China, there is an increased demand for wood. Illegal deforestation, which is then shipped to the PRC, often takes place in the Far East and in Siberia. As a result, the criminalization of the forest business in transborder Siberian and Far Eastern regions is growing. According to expert estimates, illegal logging accounts for at least $35 \%$ of the total volume of logging in these regions. At the same time, valuable species of trees are destroyed, lands are swamped after illegal logging, and there is a slow reproduction of forest resources. The government of the People's Republic of China pursues a policy of reducing deforestation in its country, increasing the forest cover of the territory and increasing its wood imports. In Russia, the annual area of forest planting is thirty times less than the average annual area of forest planting in China and is approximately two hundred thousand hectares [16].

In 2017, the Union of the Russian-Chinese Forest Industry was established, the purpose of which is to develop standards for Chinese entrepreneurs, taking into account the requirements of Russian legislation. With the help of these standards, it is planned to certify Chinese enterprises intending to conduct forest business in Russia.

With the trans-border interaction of the Russian regions and East Asian countries, unfortunately, there is a degradation of aquatic ecosystems. This is true for the following large rivers flowing through the territory of Russia, China and Mongolia: Selenga, Amur, Argun, Sungari and others. The Russian government is making efforts to solve this problem. For example, agreements were reached with Mongolia on the export of Russian electricity instead of building a hydropower station on the Selenga, which could cause irreparable environmental damage. The ecological situation at Lake Baikal is deteriorating, in which $20 \%$ of the world's 
freshwater reserves are concentrated. One of the main reasons for the deterioration of the ecological situation on Baikal is the transfer of pollutants from neighboring countries. In order to prevent the degradation of the ecosystem of Baikal, the Russian Federation and the Mongolian People's Republic create trans-border specially protected natural territories in order to preserve the biological diversity of the ecosystems of the border areas and to conduct environmental monitoring and nature studies. It is planned to expand cooperation on the study of individual species of animals that constantly migrate across the state border of Russia and Mongolia. A Russian-Chinese-Mongolian trans-border reserve Dauria and several others have been created.

Russia has not ratified the Espoo 1991 Convention on Environmental Impact Assessment in Trans-border Regions; did not sign or ratify the Aarhus Convention (1998) on access to information, public participation in decision-making and its access to justice on environmental issues. This holds back the ecological modernization of Russia. The ratification of these documents allows requiring a strategic environmental assessment (SEA) of the Silk Road trans-border projects and an assessment of their multiplicative effects. Some regions: Zabaykalsky Krai, Amur Oblast and Kemerovo Region carry out SEA of new projects. The following measures can be used to improve the state environmental regulation of the Eurasian integration process: the development of low-carbon energy and energy-efficient technologies, the use of modern agricultural technologies, the course towards the formation of a green economy, the harmonization of environmental legislation of cooperating Eurasian countries.

\section{Conclusion}

Thus, it was revealed that in the conditions of economic integration of the trans-border regions of Siberia and the Far East with the East Asian countries, the environmental burden in these regions is higher than the average Russian indicators; These regions have a negative dynamic of environmental ratings and low positions in them: from the 61st (Primorsky Krai) to the 82nd (Irkutsk Oblast). The strongest decrease in the environmental rating is observed for the Republic of Buryatia (from the 8th in 2010 to the 80th in 2018). This allows us to conclude that the existing model of Eurasian integration is in crisis, is not sufficiently efficient and a transition to an energy and resource saving model, to a green economy is required. This is the novelty of the study. The elements of the novelty of the article include the study of the relationship of the Chinese project "The Silk Road Economic Belt", the economic integration between the Russian and Chinese border regions and its environmental consequences. This is a new aspect of the study of Eurasian integration, a deep study of which makes it possible to identify existing problems and outline measures to resolve them. The government of Russia and the East Asian border countries took the course on a green economy. This will reduce the environmental burden on the environment during economic integration.

The article was prepared with the grant support of the Russian Foundation for Basic Research, project № 19-01000318.

\section{References}

[1] S.N. Bobylev, S.V. Soloviova, K.S. Sitkina, Indicators of sustainable development of the Ural region, Economy of the region, 34, 2, 10-16 (2013).

[2] D. Meadows, J. Randers, D. Meadows, Limits to Growth: The 30-Year Update, 357 (2007).

[3] P.A. Minakir, Expectations and realities of the "Turning East" policy, Economy of the region, 13, 4, 1016-1029 (2017).

[4] I. Drobysheva, From local projects to trans-border cooperation, China implements 28 projects worth $\$ 4$ billion in the Far East, Rossiyskaya gazeta (29 December 2017) [Electronic resource]. Available at: $\quad$ https://rg.ru/2017/12/29/kitaj-realizuet-nadalnem-vostoke-28-proektov-na-4-mlrddollarov.html (Accessed: 29.04.2019).

[5] S. Yongmin, S. Yuefang, Z. Gang, Black or Green? Economic growth patterns in the chain of low carbon carbon targets, J. of Resources and ecology, 6, 5, 310-317 (2015).

[6] T.A. Selishcheva, N.V. Sopina, E.S. Gavrilyuk, Economy of the Far East: Eurasian Integration, 387-394 (2018).

[7] T.A. Selishcheva, D.Iu. Miropolskii, S.A. Diatlov, etc., Problems and prospects of countries of the EEU countries, Int. J. of Supply Chain Management, 7, 5, 886-893 (2018).

[8] D.Iu. Miropolskii, T.A. Selishcheva, S.A. Diatlov, etc., Regional Development and Centralization of International Business of Chains, 7, 6, 684-692 (2018).

[9] Environmental risks of Russian-Chinese transborder cooperation [Electronic resource]. Available at: https://wwwf.ru/data/shvarts/Russiachina_for_web.pdf (Accessed: 20.05.2019).

[10] Rating of the Regions (2010) [Electronic resource]. Available at: http://www.mpr73.ru/press/berichte_Interviews/? ELEMENT_ID = 1441 (Accessed: 15.04 .2019 ).

[11] The cleanest and most polluted regions of Russia, environmental rating (2015) [Electronic resource]. Available at: http://vedic.su/publ/ehkologija_rossii/ehko_rejtin g_2015/29-1-0-59 (Accessed: 15.04.2019).

[12] Ecological rating of regions of the Russian Federation [Electronic resource]. Available at: http://www.greenpatrol.ru/sites/default/files/pictu res/ekologicheskiy_reyting__osen_2018._prilozhenie 2_1.pdf (Accessed: 15.04.2019).

[13] A. Levintal, The Chinese control up to $80 \%$ of agricultural land in the Jewish Autonomous 
Region [Electronic resource]. Available at: https://www.eaomedia.ru/news/445017 (Accessed: 27.07.2018).

[14] N.E. Antonova, Silk Road Economic Belt: Is There an Opportunity for the Development of the Bioresource Sector of the Far East?, EKO, 7, 3957 (2016).

[15] Forest in exchange for investment. EastRussia, Information and Analytical Agency "East of Russia" (8 November 2017) [Electronic resource]. Available at: https://www.eastrussia.ru/material/les-v-obmenna-investitsii (Accessed: 29.04.2019).

[16] Y. Cheng, Do National Policies Contributete to Regional Trans-border Integration?, The Case of the Program of Cooperation between Northeast China and Russia 's Far East and Eastern Siberia (2009-2018), London, Palgrave Macmillan, 202228 (2015). 